\title{
Evaluation Of Lipid Peroxidation And The Level Of Some Antioxidants In People Under General Anesthesia
}

\author{
Wasan K. Ali \\ Department of Chemistry / College of Science \\ Mosul University
}

Received

19 / 01 / 2009
Accepted

$05 / 05 / 2009$

\section{|ldill}

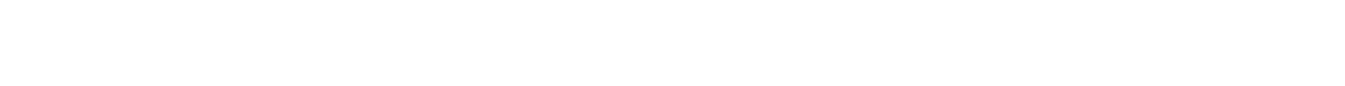

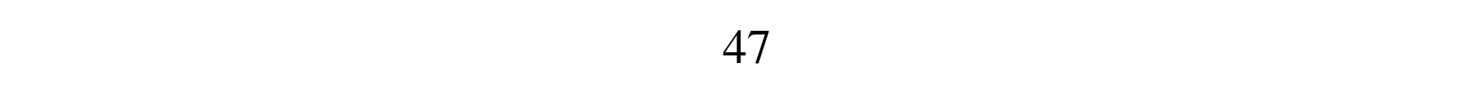

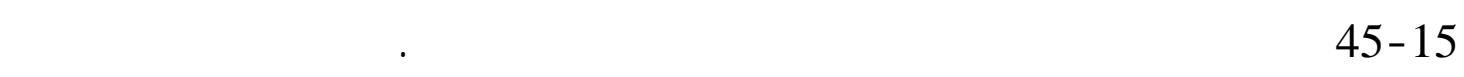

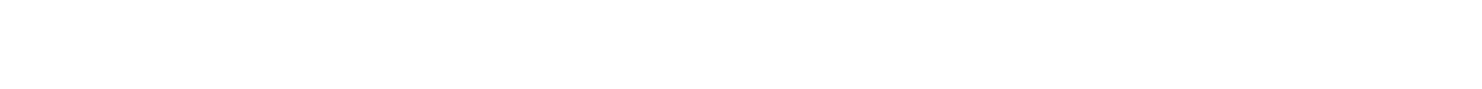

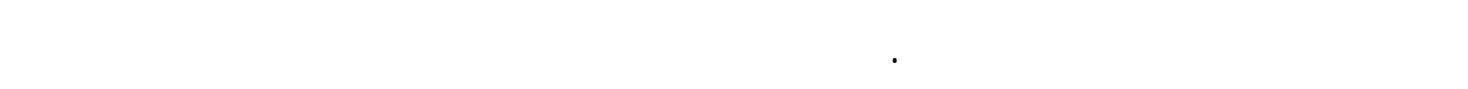

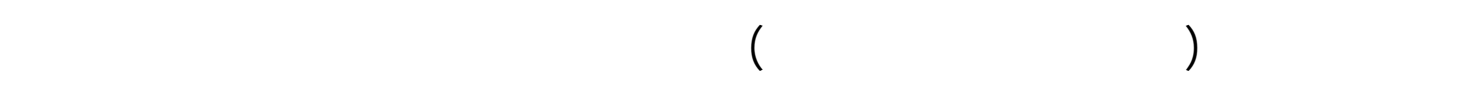

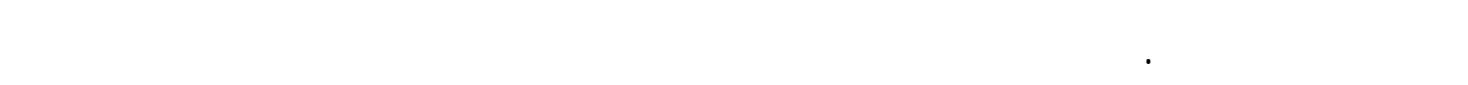

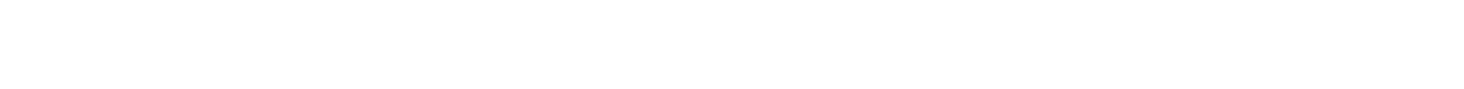
تهت التخدير العلم مقارنة بالعينت قبل التخدير.

\section{ABSTRACT}

This research includes study of the effects of general anesthesia on lipid peroxide formation and some antioxidant system in serum of patients with appendix surgery. Forty seven patients under general anesthesia with age range of 15-45 years living in Mosul city were selected. The level of serum malondialdehyde (MDA), reduced form of glutathione (GSH), superoxide dismutase (SOD), uric acid, albumin and ceruloplasmin were measured. The results showed a significant increased in MDA level (as an index of lipid peroxidation) in patients under pentothal anesthesia in comparison with preoperative samples. On the other hand, patients under general anesthesia had decreased GSH concentration, SOD activity, uric acid, albumin and ceruloplasmin concentration when compared with preoperative samples. 


\section{INTRODUCTION}

Despite improvements in surgical techniques, anaesthesia, is associated with oxidative stress. ${ }^{1}$ Oxidative stress is a disturbance in the balance between the formation of oxidizing species (reactive oxygen species and other radicals) and their effective removal by protective antioxidants (AOX). Overwhelming radicals generated in the bloodstream and tissues can induce oxidative damage, representing by lipid peroxidation, to the cell membranes, lipoproteins, proteins, and deoxyribonucleic acid. ${ }^{2}$ The peroxidation of membrane phospholipids generates malondialdehyde (MDA) - an end product of lipid peroxidation and a marker of oxidative stress produced during general anesthesia in dogs. ${ }^{3}$

On the other hand, recent interest has been focused on the role of AOX to prevent such injury produced by oxidative stress. ${ }^{4}$ Glutathione, superoxide dismutase, uric acid, albumin, and Ceruloplasmin possesses antioxidant activity, were used in the present study. On this basis, measurements of parameters for oxidative stress are a good technique to express the degree of cell damage. ${ }^{1}$ Accordingly, the aim of this study was to measure the degree of lipid peroxidation, expressed by plasma MDA, which is a reliable index for oxidative stress in vivo, and antioxidative system activity changes in patients with appendectomy under general anesthesia by Pentothal and flothin.

\section{SUBJECTS AND METHODS}

\section{The Experiment}

Forty seven patients aged 15-45 years, 21 men and 26 women, undergoing general anesthesia of appendix surgery (appendectomy), were consecutively enrolled in a prospective observational setting.

Anaesthesia was induced with pentothal $5 \mathrm{mg} / \mathrm{kg}$, which acts as hypnotic in addition to anesthetic agent. Sodium thiopental, better known as Sodium Pentothalis, is a rapid-onset short-acting barbiturate general anaesthetic. ${ }^{5}$ Following intravenous injection, the drug rapidly reaches the brain and causes unconsciousness within 30-45 seconds, and in about 510 minutes the concentration is low enough in the brain such that consciousness returns. For this reason, thiopental is not used to maintain anesthesia in surgical procedures. Instead, anesthesia is usually maintained with an inhaled anesthetic gas, ${ }^{6}$ flothin $1-2 \%$ which continue to the end of operation, usually for 35-50 min. (the time consuming for appendectomy procedures).

This study was conducted in Al-Salam Teaching Hospital, Mosul City, and approved by the local institutional review board, and all of the participants provided written informed consent. None of the patients had a history of previous diabetics, chronic inflammatory conditions, hepatic 
or respiratory disease, and those on antioxidants, vitamin or other medication were excluded from the study.

\section{Blood Sampling And Biochemical Analyses}

Venous blood samples were drawn into plain tubes. Two blood samples were collected from each patient, one was collected 5 minutes before operation (preoparation), and another was taken 30 minutes after the first sample (during or intraoperation). The tubes were centrifuged for ten minutes at $4000 \mathrm{xg}$. and the serum was separated. The analytical determinations described below were either performed immediately, or serum was stored at $-20^{\circ} \mathrm{C}$ and used within 72 hours.

Lipid peroxidation was estimated by determination of the level of serum malonyldialdehyde using thiobarbituric acid reaction (TBARS) according to the modified method of Gilbert et al., ${ }^{7}$ while the level of glutathione was measured by a modified procedure utilizing Ellman`s reagent. $^{8}$ The activity of SOD levels in blood serum was determined using photochemical method described by Brown and Goldstein. ${ }^{9}$ This methods depends on an indirect approach to determine the SOD activity through the change in formazene absorbance formed from the reduction of $\mathrm{O}_{2}{ }^{-2}$, (which is produced by radiating the sample of serum with light) for nitroblue tetrazolum (NBT) dye. Decreased difference in formazene absorbance means increased SOD activity. Ceruloplasmin was measured by modified method described by Menden et al. ${ }^{10}$ The level of Uric Acid $^{11}$ and Serum Albumin ${ }^{12}$ were also measured.

\section{Data Analysis}

Data analyses were performed using SPSS software version 10.0. Results were reported as mean \pm standard deviation. Comparisons between groups (pre-operative and intra-operative data) were carried out using the Independent-Samples $\mathrm{T}$-Test. A value of $\mathrm{P}<0.05$ indicates statistical significance. ${ }^{13}$

\section{RESULTS}

The effects of general anesthesia induced by pentothal in pateients with appendix surgery on lipid peroxidation and antioxidant status are presented in table (1). MDA was significantly increased in patients exposed to pentothal general anesthesia, while GSH, SOD activity (expressed as increased formazene absorbance), uric acid, albumin and ceruloplasmin were decreased significantly in comparison with preoperative samples that are not exposed to anesthesia. 
Table(1): Effects of anesthesia in lipid peroxidation and antioxidant status.

\begin{tabular}{|c|c|c|}
\hline Parameters & $\begin{array}{l}\text { Pre-oparative samples } \\
\qquad(\mathrm{n}=47)\end{array}$ & $\begin{array}{c}\text { Intra-operative samples } \\
((n=47)\end{array}$ \\
\hline $\begin{array}{c}\text { Malondialdehyde }(\mu \mathrm{mol} / \mathrm{L}) \\
(\mathrm{MDA})\end{array}$ & $3.77 \pm 0.664$ & $\begin{array}{c}* * * \\
4.37 \pm 0.717\end{array}$ \\
\hline $\begin{array}{c}\text { Glutathione }(\mu \mathrm{mol} / \mathrm{L}) \\
(\mathrm{GSH})\end{array}$ & $16.95 \pm 1.825$ & $\begin{array}{c}* * * \\
9.58 \pm 1.722\end{array}$ \\
\hline $\begin{array}{c}\text { Superoxide Dismutase } \\
\text { (SOD) }\end{array}$ & $0.13 \pm 0.008$ & $\begin{array}{c}* * * \\
0.14 \pm 0.011\end{array}$ \\
\hline Uric Acid $(\mu \mathrm{mol} / \mathrm{L})$ & $311.17 \pm 49.177$ & $\begin{array}{c}* * * \\
260.15 \pm 23.769\end{array}$ \\
\hline Albumin (g/L) & $40.75 \pm 5.663$ & $\begin{array}{c}* * * \\
35.14 \pm 4.254\end{array}$ \\
\hline Ceruloplasmin $(\mu \mathrm{mol} / \mathrm{L})$ & $317.04 \pm 39.989$ & $\begin{array}{c}* * * \\
264.15 \pm 20.991\end{array}$ \\
\hline
\end{tabular}

- Values are expressed as means $\pm \mathrm{SE}$.

- *** Significantly different from the control $(\mathbf{p}<0.001)$

- SOD activity expressed by the difference in formazene absorbance before and after irradiation. (Increased absorbance means decreased SOD activity).

\section{DISCUSSION}

In the present study, we evaluated global oxidative stress-induced anesthesia by means of MDA, and we showed significant differences in the lipid peroxidation represented by MDA between the groups investigated. These results can be compared with those obtained by other investigators, ${ }^{14}$ in which plasma lipid peroxidation levels were found to be higher in those subjects exposed to anesthetic gases. Similar results regarding lipid peroxidation were described in another study ${ }^{15}$ revealed an increase of values of MDA, which was caused by the general anesthetic drugs. Increased lipid peroxidation in the blood of exposed subjects warns that oxygen free radicals have increased in the body and thus might attack cells, which, in the longterm, results in multi-organ damage. ${ }^{14}$

On the other hand, the antioxidant defense system was affected by free radical injury in anesthesia and surgery personnel who had been exposed to inhalation anesthetics. ${ }^{16}$ In the present study, GSH was decreased significantly in patients after exposure to anesthesia.

Although a number of mechanisms exist by which aerobic organisms normally prevent or limit the damage caused by toxic oxygen metabolites, the defense mechanisms that first evolved seem to have been produced by the SOD. ${ }^{17}$ Superoxide radicals are highly reactive products that are known to induce various pathological changes in the subject. SOD is an enzyme that scavanges superoxide radicals. ${ }^{18}$ In the present study, SOD was decreased significantly in patients after exposing to general anesthesia. This can be compared with others, in which the mean 
plasma SOD like activity before the anesthetic induction in surgical men of all groups was $5.70 \pm 0.41 \mathrm{U} \cdot \mathrm{ml}^{-1}$ and a marked reduction in plasma SOD like activity was obtained during enflurane with $\mathrm{N}_{2} \mathrm{O}$ anesthesia. ${ }^{18}$

Another antioxidant parameter, uric acid, was included in the present study. Uric acid was decreased significantly in patients following thiopental anesthesia. Similar result was obtained by Tooru et al. ${ }^{19}$ in which serum uric acid concentration was significantly decreased from 2 hours after the start of anesthesia to 3 hours after the end of anesthesia in the group under propofol anesthesia. In contrast Giler et al, ${ }^{20}$ suggest no changes in uric acid level following halothane or nitrous oxide-oxygen and relaxant anesthesia.

In the normal physiological status of the organism, lipid peroxidation is strictly regulated by the antioxidative system. Metalbinding proteins, such as ceruloplasmin and albumins can exhibit this antioxidative properties. ${ }^{21}$ Accordingly, Albumin and ceruloplasmin were decreased significantly in patients during operation in the present study. This may be contributed to increased free radical formation due to pentothal anesthesia.

\section{CONCLUSION}

We concluded that the antioxidant defense system was affected by free radical injury in anesthesia who had been exposed to pentothal general anesthesia.

\section{REFERENCES}

1) Gerritsen WB, van Boven WJ, Driessen AH, Haas FJ, Aarts LP. Offpump vs. on-pump coronary artery bypass grafting: oxidative stress and renal function. Eur J Cardiothorac Surg 2001; 20(5): 923-939.

2) Gutteridge JMC, Mitchell J. Redox imbalance in the critically ill. $\mathrm{Br}$ Med Bull 1999; 55: 49-75.

3) Simeonova GP, Todorova II, Gadjeva V, Dinev DN. Evaluation of lipid peroxidation associated with three anesthetic protocols in dogs. Revue Méd. Vét 2004; 155 (12): 602-605.

4) Crimi E, Liguori A, Condorelli M, Cioffi M, Astuto M, Bontempo P, Pignalosa O, Vietri MT, Molinari AM, Sica V, Corte FD, Napoli C. The Beneficial Effects of Antioxidant Supplementation in Enteral Feeding in Critically Ill Patients: A Prospective, Randomized, Double-Blind, Placebo-Controlled Trial. Anesth Analg 2004; 99: 857-863.

5) Miller RD. (2005) "Miller's Anesthesia" $6^{\text {th }}$ ed New York. P: 320.

6) Morgan DJ, Blackman GL, Paull JD, Wolf LJ. Pharmacokinetics and plasma binding of thiopental. II: Studies at cesarean section. Anesthesiology 1981; 54(6): 474-80.

7) Gilbert HS, Stump, DD and Roth EF. 1984. A method to correct for errors caused by generation of interfering compounds during erythrocyte lipid peroxidation. Anal. Biochem., 137: pp.282- 286. 
8) Sedlak J, Lindsay RH. Anal. Biochem. 1968; 192. (Cited by AlZamely OM, Al-Nimer MS, Al-Muslih RK. Detection the level of peroxynitrite and related with antioxidant status in the serum of patients with acute myocardial infarction. Nation J Chem 2001; 4: 625-637).

9) Brown, M. S., and Goldstein. 1983. Ann. Rev. Biochem. 52, 223. (cited by Al-Zamely, O. M., Al-Nimer M. S., Al-Muslih R. K. 2001. Detection the level of peroxynitrite and related with antioxidant status in the serum of pateints with acute myocardial infarction. Nation. J. Chem. 4:625-637.)

10) Menden, E. E; Boiano, J.M, Murthy, L. and petering, H. G. (1977). "Modification of phenylene diamine oxidase method to permit nonantomated ceruloplasmin determination in batches of rat serum or plasma micro samples. Analytical. 10: 197-204.

11) العمري، محمد رمزي (1986) الكيمياء للسريرية العملي، دار القني الطباعة والن شرر مؤسسة المعاهد الفنية.

12) Varley H, Gowenlock $A H$ and Bell M. (1980). "Practical clinical biochemistry”. Vol. (1), London, pp. 222-225, 553-555.

13) Steel, R. G. D. and Torrie, J. H., 1980. Principles and Procedures of Statistics. $2^{\text {nd }}$ ed. New York: McGraw-Hill Book Company, Inc. 1960: pp.87-80, 107-109, 125-127.

14) Malekirad A A, Ranjbar A, Rahzani K, Kadkhodaee M, Rezaie A, Taghavi B, Abdollahi M. Oxidative stress in operating room personnel: occupational exposure to anesthetic gases. Human Exper Toxicolo 2005; 24 (11): 597-601.

15) Neri $S$, Mondati E, Bruno CM. Free radicals in anesthesia and the role of exogenous antioxidants. Riv Eur Sci Med Farmacol 1994; 16 (5-6): 125-30.

16) Türkan H, Aydin A, Sayal A. Effect of Volatile Anesthetics on Oxidative Stress Due to Occupational Exposure. World J Surgery 2005; 29 (4): 540-542.

17) Reilly PM, Schiller HJ, Bulkley GB. Pharmacologic approach to tissue injury mediated by free radicals and other reactive oxygen metabolites. Am J Surg 1991; 161: 488-503.

18) Kudou $M$, Kudou $T$, Matsuki $A$. Changes in plasma superoxide dismutase like activity during general anesthesia and surgery in man. Masui 1990; 39(9): 1172-1177

19) Tooru $S$, Kiichi $T$, Hideki $O$, Kazuko $O$, Katsuhito $H$, Isao H. The Influence of Propofol Anesthesia on Uric Acid Excretion. J Jap Dent Soc Anesthes 2004; 32 (2): 218-222.

20) Giler SH, Sperling O, Ventura E, Levy E, Urca I, De Vries A. Effect of methoxyflurane anesthesia on serum uric acid in man. Biomedicine 1977; 27(1): 13-15.

21) Romero FJ, Boch-Morell F, Romero MJ, Jareno EJ. Lipid peroxidation products and antioxidants in human disease. Environ Health Perspect 1998; 106 (suppl 5): 1229-34. 